\title{
Modelling protein synthesis, a step to an accurate estimate of net primary production: Phaeocystis pouchetii colonies in Belgian coastal waters
}

\author{
Christiane Lancelot ${ }^{1}$, Sylvie Mathot ${ }^{1}$ \& Nicholas J. P. Owens ${ }^{2}$ \\ ${ }^{1}$ Groupe de Microbiologie des Milieux Aquatiques, Université libre de Bruxelles, 50, avenue F. D. Roosevelt, B-1050 Brussels, \\ Belgium \\ ${ }^{2}$ Institute for Marine Environmental Research, Prospect Place, The Hoe, Plyrnouth PL1 3DH, England
}

\begin{abstract}
Light and dark rates of net protein synthesis by Phaeocystis pouchetii colonies were measured in Belgian coastal waters during the spring bloom of 1984 by following ${ }^{14} \mathrm{C}$-bicarbonate and ${ }^{15} \mathrm{NO}_{3} /{ }^{15} \mathrm{NH}_{4}^{+}$assimilation into cellular proteins during natural light:dark cycles. A close agreement was found between the 2 tracer methods. Ambient inorganic nitrogen was shown to be the most important factor controlling protein synthesis in the light, which was considered to proceed at a constant rate in the whole euphotic layer. Protein synthesis in the dark, on the other hand, was found to be controlled by both inorganic $\mathrm{N}$ and 'previous light history' of the cells. The relation between specific protein synthesis and external inorganic nitrogen obeyed Michaelis-Menten kinetics for both light and dark processes. The Michaelis-Menten constant $\mathrm{K}$, was $4 \mu$ moles $\mathrm{N}^{-1}$ while the maximum specific protein synthesis rates $\mathrm{p}_{\max }$ were respectively 3 and $1.8 \% \mathrm{~h}^{-1}$ for the light and dark processes. The relation between protein assimilation in the dark and 'previous light history' could be expressed by a linear relation between dark specific protein synthesis and the number of hours spent at $\geqslant 8 \mathrm{~J}$ $\mathrm{cm}^{-2} \mathrm{~h}^{-1}$, the energy threshold for the occurrence of dark protein synthesis. From the knowledge of these control mechanisms a simple mathematical model was established in order to calculate daily integrated net primary production from the hourly variations of light intensity in the water column and ambient inorganic $N$ concentrations. These estimates have been compared with those calculated from classical methods for measurements of primary production.
\end{abstract}

\section{INTRODUCTION}

Classical models for estimating primary production in aquatic environments are based on the relation between photosynthesis rate and available light intensity (see review by Platt \& Gallegos 1980). Such models are unsatisfactory for accurate estimates of phytoplankton growth or net primary production because they do not take into account the cellular biochemistry associated with both light-dependent and independent processes. Indeed, basic physiological studies with pure cultures (Cook 1966, Foy \& Smith 1980, Redalje 1980, Rivkin et al. 1982, Cuhel et al. 1984) report some uncoupling between division and photosynthesis rates by phytoplankton. Some phytoplankton continue to divide in the dark and to synthesize cellular constituents at the expense of storage products, the synthesis of which is controlled by light.

Protein synthesis, because of the functional nature of these cellular compounds, appears therefore to be the most appropriate index of growth for natural phytoplankton assemblages. Previous sophisticated tracer experiments with ${ }^{14} \mathrm{C}$ and ${ }^{35} \mathrm{~S}$ (Cuhel et al. 1984, Priscu \& Priscu 1984, Lancelot \& Mathot 1985aj provided evidence that natural phytoplankton which encounters an adequate photoperiod can store sufficient carbon and energy for net protein synthesis in the dark under conditions of non-nitrogen limitation. From these studies it can be concluded that the potential for growth during the night by natural phytoplankton is determined by a combination of environmental factors among the most important of which are 'prior light intensity history' which determines the pool size of respiratory substrates and nutrient status defined by external and intracellular pools of nutrients.

The knowledge of the control by these factors of both light and dark protein synthesis may therefore be the basis for the establishment of a mathematical model which calculates phytoplankton growth in the water column. This model would combine the physical and 
chemical properties of the water column and the physiological characteristics of phytoplankton growth.

Such a study was conducted during spring 1984 in Belgian coastal waters. At this time of the year, Phaeocystis pouchetii colonies made up more than $90 \%$ of phytoplankton biomass (on basis of microscopic cell counts) accompanied by only a few diatoms. Their growth was controlled by external inorganic nitrogen concentrations (Lancelot \& Mathot unpubl.).

The main characteristics of the carbon metabolism by these colonies, with each individual colony acting as a biological entity, were described by Lancelot \& Mathot (1985b) and Veldhuis \& Admiraal (1985). Evidence of cellular protein synthesis at night, under conditions of non-nitrogen limitation, was provided by the former. Carbon and energetic needs for this process are provided for, in large part, by the catabolism of exopolymers which compose the mucilaginous envelope of the colonies and whose synthesis is controlled by light intensity (Lancelot \& Mathot unpubl.).

This paper describes a detailed study of carbon and nitrogen metabolism by natural Phaeocystis pouchetii colonies at different stages of their growth and by $\mathrm{N}$ sufficient cultured colonies growing under various light:dark cycles. Particular emphasis was devoted to protein synthesis measured kinetically during natural light:dark cycles by means of 2 isotopes, ${ }^{14} \mathrm{C}$ as bicarbonate and ${ }^{15} \mathrm{~N}$ as nitrate and ammonia. The use of these isotopes in parallel provides quantitative but also qualitative information on nitrogen nutrition and the mechanisms of cellular protein synthesis by this colonial algae. The carbon and nitrogen assimilation data are used as the basis for the establishment of a mathematical model which calculates $P$. pouchetii growth in the water column.

\section{MATERIAL AND METHODS}

\section{FieId experiments}

Collection of samples. Experiments were performed in Belgian coastal waters at $51^{\circ} 21^{\prime} \mathrm{N}, 2^{\circ} 48^{\prime} \mathrm{E}$ during spring 1984. Water samples were collected at sunrise at a depth of $3 \mathrm{~m}$ with $5 \mathrm{l}$ Niskin bottles. One l was immediately filtered through GF/F Whatman filters for chlorophyll a determinations in the retained particulate material; inorganic forms of nitrogen were measured on the filtrate, directly after sampling. A further $100 \mathrm{ml}$ of seawater was fixed with Lugol's solution for phytoplankton determination. Integrated measurements of total incident solar radiation were collected every $30 \mathrm{~min}$ by the 'Institut Royal Météorologique de Belgique', $10 \mathrm{~km}$ away from the sampling station, by means of a pyronometer. PhAR (Photosynthetic Active Radiation) was calculated by means of appropriate conversion factors reported in Parsons et al. (1977).

Chemical analysis. Chlorophyll a was measured by the spectrophotometric method of Lorenzen (1967). Nitrate and nitrite were determined according to the procedure described by Amstrong et al. (1967). Ammonium was measured by the phenol hypochlorite method of Slawyk \& McIsaac (1972).

Tracer experiments. Tracer experiments were started at noon and were continued until sunrise. Incubations were run in parallel in seawater-cooled incubators under full incident solar radiation.

${ }^{14} \mathrm{C}$-bicarbonate incorporation measurements. ${ }^{14} \mathrm{C}$ bicarbonate ( $45 \mathrm{mCi}$ mmole ${ }^{-1}$ ) was added at zero time at concentrations of 10 to $25 \mu \mathrm{Ci}$ per $100 \mathrm{ml}$ of seawater. At intervals, during the light: dark cycle, $100 \mathrm{ml}$ were filtered according to the procedure described in Lancelot \& Mathot (1985a). Biochemical separation of intracellular compounds was performed as reported by these authors. Mucilaginous substances which compose the colonial envelope were isolated by ethanol precipitation ( 3 vol.). Polysacchandes were collected by centrifugation, washed with ethanol and dried. Radioactivity of all biochemical fractions was measured by liquid scintillation and counting efficiency was determined by internal standards.

Inorganic ${ }^{15} \mathrm{~N}$ incorporation measurements. ${ }^{15} \mathrm{NO}_{3}^{-}$ and ${ }^{15} \mathrm{NH}_{4}^{+}$(99.2 atom \%) were added at concentrations of approximately $10 \%$ of the ambient respective nutrient concentration at zero time. At sunset and sunrise subsamples of each labelled phytoplankton assemblage were filtered in duplicate on precombusted Whatman GF/F filters and rinsed with filtered seawater to remove residual ${ }^{15} \mathrm{~N}$. One subsample was used for measurements of nitrogen incorporation into cellular proteins. The protein fraction was therefore immediately isolated from other cellular constituents by hot TCA precipitation following the biochemical treatment reported in Lancelot \& Mathot (1985a). Filters were then freeze-dried for subsequent analysis. Total cellular organic nitrogen and protein-nitrogen together with their ${ }^{15} \mathrm{~N}$ content were analysed by Dumas combustion followed by isotope analysis using an MS 622 dual collector isotope mass spectrometer according to Preston \& Owens (1983).

All ${ }^{15} \mathrm{~N}$ uptake data are reported as ${ }^{15} \mathrm{~N}$ atom \% excess compared against a working standard $\left[\left(\mathrm{NH}_{4}\right)_{2} \mathrm{SO}_{4}-0.366\right.$ atom $\left.\%{ }^{15} \mathrm{~N}\right] .{ }^{15} \mathrm{~N}$ uptake rates were not corrected for dilution of the ${ }^{15} \mathrm{~N}$ isotopic enrichment resulting from regeneration of ${ }^{14} \mathrm{~N}$ during the incubation. Absolute amounts of nitrogen taken up by the cells or incorporated into the proteins were calculated by use of Collos's (1984) equation. The relative preference index (RPI) (McCarthy et al. 1977) was 
calculated for each nutrient to compare utilization relative to availability of inorganic nitrogen resources.

\section{Laboratory experiments}

Axenic cultures of Phaeocystis pouchetii colonies (strain obtained from the Marine Biological Assocation, Plymouth, U. K.) were maintained in $\mathrm{f}_{20}$ medium (Guillard \& Ryther 1962) on a 15 h:9 h light:dark cycle. Ammonia and nitrate concentrations were respectively 20 and $55 \mu \mathrm{g}$-at $\mathrm{N}^{-1}$. Illumination was $180 \mu \mathrm{E} \mathrm{m}^{-2} \mathrm{~s}^{-1}$ and temperature was kept at $10^{\circ} \mathrm{C} .{ }^{14} \mathrm{C}$-bicarbonate $(500 \mu \mathrm{Ci}$ per $\mathrm{l}$ of culture) incorporation experiments were carried out during $24 \mathrm{~h}$ on batch subcultures at $3 \mathrm{~h}: 21 \mathrm{~h}, 6 \mathrm{~h}: 18 \mathrm{~h}, 9 \mathrm{~h}: 15 \mathrm{~h}, 12 \mathrm{~h}: 12 \mathrm{~h}$ and $15 \mathrm{~h}: 9 \mathrm{~h}$ light:dark cycles. At $3 \mathrm{~h}$ intervals, subsamples were filtered and handled as described in the preceeding section.

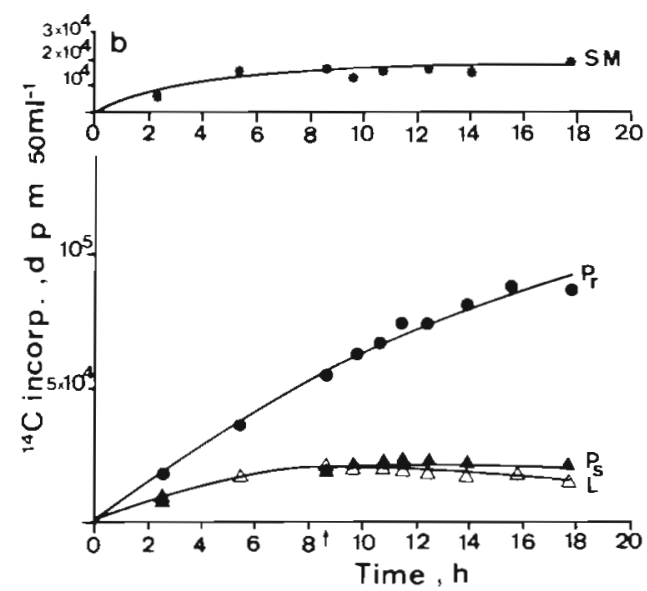

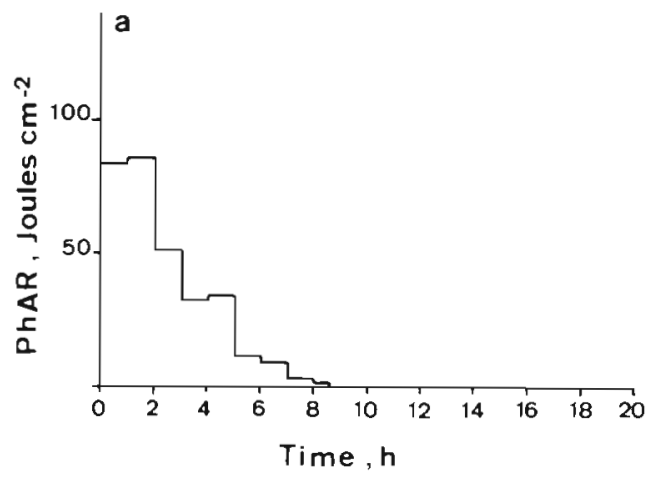

\section{RESULTS}

Kinetics of ${ }^{14} \mathrm{C}$-bicarbonate, ${ }^{15} \mathrm{~N}$-nitrate and ${ }^{15} \mathrm{~N}$ ammonia incorporation by natural population

The general trends of night protein synthesis by Phaeocystis pouchetii (its occurrence, its mechanism and the importance of nitrate and ammonia as nitrogen source), are illustrated by Fig. $1 \& 2$. These figures give results of long-term kinetics of ${ }^{14} \mathrm{C}$-bicarbonate $(\mathrm{b} \& \mathrm{c}$ ), ${ }^{15} \mathrm{~N}$-nitrate (d) and ${ }^{15} \mathrm{~N}$-ammonia (e) incorporation into cellular components by natural $P$. pouchetii colonies at the growing and stationary stage of their growth. Ambient inorganic nitrogen concentrations $\left(\mathrm{NO}_{3}^{-}+\right.$ $\mathrm{NH}_{4}^{+}$) were respectively 32.5 and $2.6 \mu \mathrm{g}$-at $\mathrm{N}^{-1}$ and
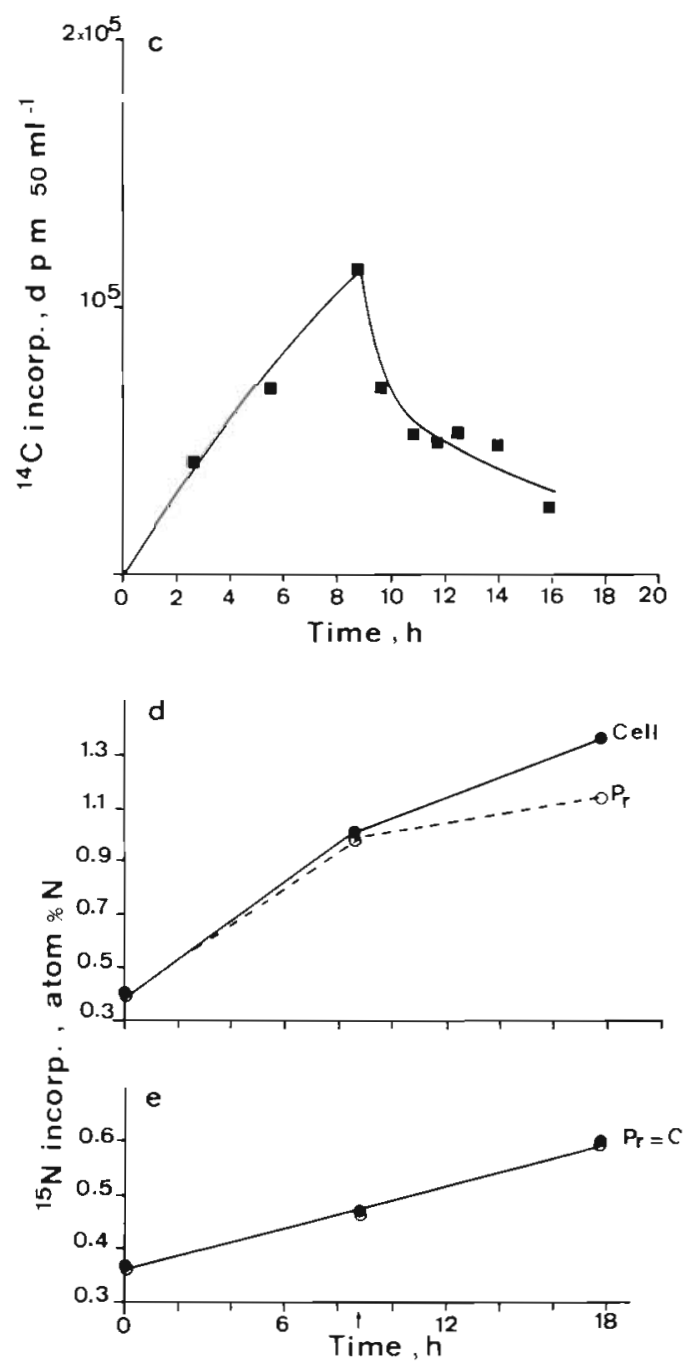

Fig. 1 Phaeocystis pouchetii. Long-term kinetics of tracer incorporation in their sub-components by natural colonies sampled May 2, 1984, in Belgian coastal waters. (a) Photosynthetic Active Radiation. (b) ${ }^{14} \mathrm{C}$-bicarbonate incorporation into cellular components. ( $\star$ ) Small metabolites (SM), ( $)$ proteins (Pr), ( $\mathbf{\Delta}$ ) polysaccharides (Ps); $(\Delta)$ lipids (L). (c) ${ }^{14} \mathrm{C}$-bicarbonate incorporation into mucilaginous compounds of the colonial matrix. (d) ${ }^{15} \mathrm{~N}$-nitrate uptake (๑) and assimilation into proteins $\mathrm{P}_{r}(0)$. (e) ${ }^{15} \mathrm{~N}$ ammonia uptake ( $)$ and assimilation into proteins $\mathrm{P}_{\mathrm{r}}(0)$. Arrows indicate sunset 
biomass as measured by chlorophyll a extraction, 11

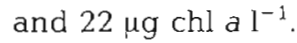

Under conditions of luxuriant ambient inorganic nitrogen, evidence is given of night protein synthesis as demonstrated by ${ }^{14} \mathrm{C}$ incorporation into proteins (Fig. 1b) and ${ }^{15} \mathrm{~N}$-inorganic nitrogen uptake and its assimilation into proteins (Fig. 1d,e). In agreement with previous work (Lancelot \& Mathot 1985b), metabolic requirements for dark nitrogen uptake and protein synthesis are mainly provided by the catabolism of mucilaginous substances, the radioactivity of which exponentially decreases during the first hours following sunset (Fig. 1c). In this particular case of nutrient abundance, however, the pool of photosynthesized mucilaginous substances seems to be insufficient to meet the energetic costs required for a night protein synthesis proceeding at the same rate as during the light period (Fig. 1b). Examination of Fig. 1d \& e shows in addition that it is the dark uptake of nitrate and mostly its assimilation into proteins that is reduced (Fig. 1d). Indeed, ammonia assimilation (Fig. 1e), an energetically less expensive process, occurs at the same rate during all the light:dark cycle. Intracellular pools of nitrate therefore most probably build up du-
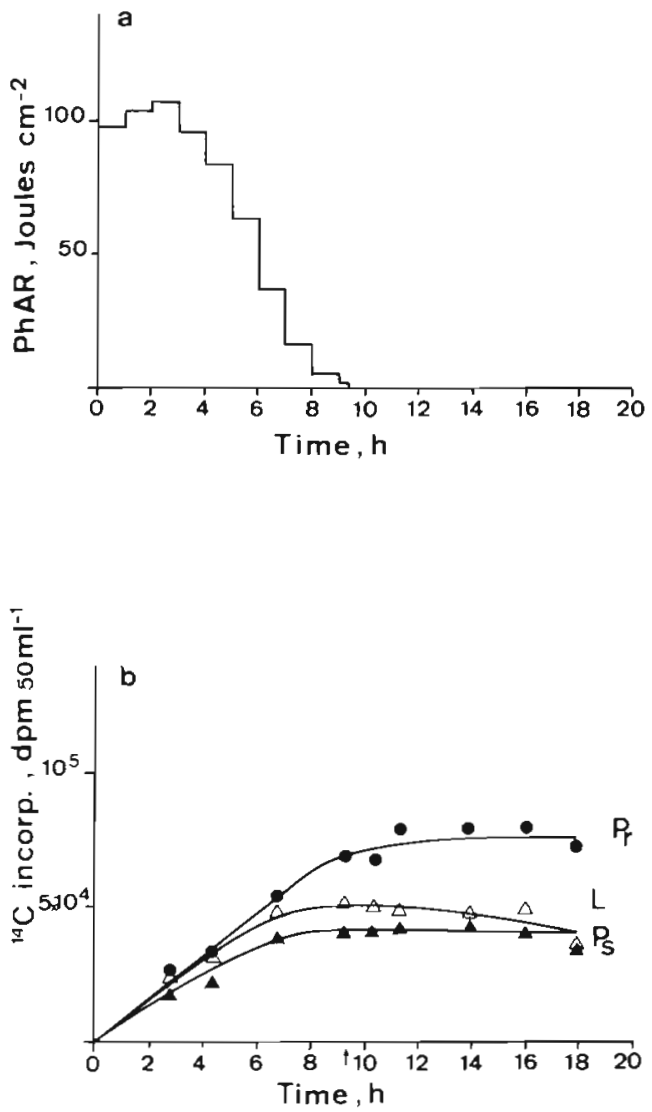

ring the night by this $\mathrm{N}$-sufficient Phaeocystis pouchetii population.

On the other hand, at the height of the bloom when biomass is the greatest and ambient inorganic nitrogen is at its lowest level, there is no indication of night protein synthesis shown either by ${ }^{14} \mathrm{C}$ (Fig. 2b) or ${ }^{15} \mathrm{~N}$ $\mathrm{NH}_{4}^{+}$(Fig. 2e) incorporation measurements. However, the radioactivity incorporated into the mucilaginous substances does show a sharp decrease during the night similar to that described above. The catabolism of these compounds is therefore used to meet part of the energetic requirements for the maintenance of cellular structure during the night. Fig. $2 d$ shows in
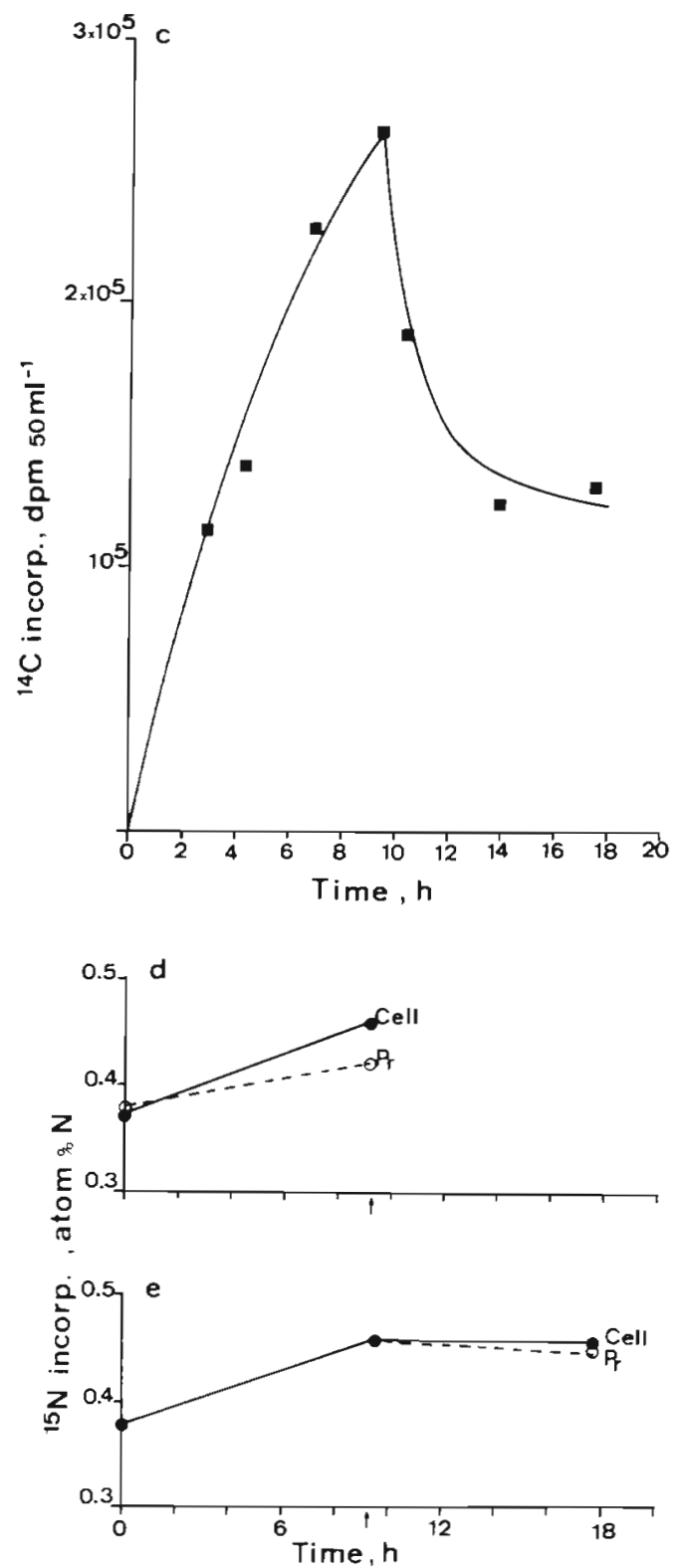

Fig. 2. Phaeocystis pouchetii. Long-term kinetics of tracer incorporation into their sub-components by natural colonies sampled May 21, 1984, in Belgian coastal waters. Symbols as in Fig. 1 
Table 1. Nitrogen cellular uptake and protein synthesis rates

\begin{tabular}{|c|c|c|c|c|c|c|c|c|c|}
\hline \multirow[t]{2}{*}{$\begin{array}{l}\text { Date of } \\
\text { sample }\end{array}$} & \multirow[t]{2}{*}{$\begin{array}{l}\text { Chl a } \\
\left(\mu g !^{-1}\right)\end{array}$} & \multicolumn{2}{|c|}{$\begin{array}{l}\text { Inorganic } N \\
\left(\mu \text { mole } N l^{-1}\right)\end{array}$} & \multirow[t]{2}{*}{ Period } & \multicolumn{2}{|c|}{$\begin{array}{c}\text { Nuptake }{ }^{1} \\
\left(\mu \mathrm{g} \mathrm{N} \mathrm{l}^{-1} \mathrm{~h}^{-1}\right)\end{array}$} & \multicolumn{2}{|c|}{$\begin{array}{l}N \text {-protein synthesis } \\
\left(\mu g \mathrm{Nl}^{-1} \mathrm{~h}^{-1}\right)\end{array}$} & \multirow[t]{2}{*}{$\begin{array}{c}\text { C-protein synthesis } \\
\left(\mu g C l^{-1} h^{-1}\right)\end{array}$} \\
\hline & & $\mathrm{NH}_{4}^{+}$ & $\mathrm{NO}_{3}^{-}$ & & $\mathrm{NH}_{4}^{+}$ & $\mathrm{NO}_{3}^{-}$ & $\mathrm{NH}_{4}^{+}$ & $\mathrm{NO}_{3}$ & \\
\hline \multirow[t]{2}{*}{$24 \mathrm{Apr} 84$} & 9.48 & 2.5 & 30 & Light & 0.68 & 3.2 & 0.65 & 2.1 & 8.6 \\
\hline & & & & Dark & 0.74 & 1.3 & 0.65 & 0.4 & 4.3 \\
\hline \multirow[t]{2}{*}{10 May 84} & 20.6 & 4.6 & 8 & Light & 3.4 & 3.6 & 2.42 & 1.91 & 16.2 \\
\hline & & & & Dark & 1.93 & 2.37 & 1.10 & 1.86 & 9.7 \\
\hline \multirow[t]{2}{*}{14 May 84} & 20.3 & 0.6 & 2 & Light & 0.87 & 1.76 & 0.85 & 0.92 & 9.6 \\
\hline & & & & Dark & 0 & 0 & 0 & 0 & 0 \\
\hline \multirow[t]{2}{*}{21 May 84} & 9.9 & 0.8 & 8 & Light & 0.62 & 0.70 & 0.39 & 0.47 & 6 \\
\hline & & & & Dark & 0.39 & 0.63 & 0.32 & 0.35 & 5 \\
\hline 'Estimated & ${ }^{15} \mathrm{Ne}$ & ment & erime & 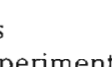 & & & & & \\
\hline
\end{tabular}

addition that nitrate taken up during the light period is not entirely devoted to protein synthesis but probably stored as an intracellular nitrogen reservoir.

Inorganic nitrogen nutrition and protein synthesis by Phaeocystis pouchetii colonies during the course of the spring bloom 1984 are summarized in Table 1. This table shows data relative to the light and dark nitrogen uptake and protein synthesis rates as measured at different stages of the spring bloom. The beginning of the bloom excepted, ammonia and nitrate are almost equally important as nitrogen sources for the growth of $P$. pouchetii colonies, agreeing with previous studies on nitrogen nutrition by shelf phytoplankton (Eppley et al. 1979, Glibert et al. 1982, Probyn 1985) which report about $60 \%$ nitrate use. Also, the Relative Preference Index (RPI) values for the 2 nutrients (Table 2) are in good agreement with these previous studies (McCarthy et al. 1977, Glibert et al. 1982, Probyn 1985), with ammonia generally the preferred substrate. In agreement with this, ammonia taken up by the cells is generally directly used for protein synthesis during the night as well as during the light period.

Conversely, uptake rates of nitrate are always significantly higher than their assimilation into proteins suggesting the involvement of intracellular storage reservoirs of nitrogen. The processes of dark nitrogen uptake and assimilation proceed at a lower rate than during the photoperiod. At high levels of external inorganic nitrogen, it is likely that dark protein syn-

Table 2. Relative preference index (RPI) for ammonium and nitrate uptake as a function of ambient inorganic nitrogen

\begin{tabular}{|ccc|}
\hline Date of sample & RPI ammonium & RPI nitrate \\
\hline 2 May 84 & 2.1 & 0.9 \\
10 May 84 & 1.3 & 0.8 \\
14 May 84 & 1.4 & 0.9 \\
21 May 84 & $5.1-5.2$ & 0.58 \\
\hline
\end{tabular}

thesis would be limited by the size of the reserve products pool, the catabolism of which provides energy and carbon skeletons required for protein synthesis.

\section{Protein synthesis by cultured colonies grown under several light:dark cycles}

Energy requirements for dark protein synthesis could be simply expressed in terms of 'previous light history' i.e. the available light during the photoperiod preceeding the dark period.

The effect of the photoperiod duration on dark protein synthesis was tested on cultured N-sufficient Phaeocystis pouchetii colonies pre-incubated at constant illumination for different light:dark cycles. Light intensity was chosen close to the light saturation constant $\mathrm{I}_{\mathrm{k}}$ characteristic of $P$. pouchetii colonies in Belgian coastal waters $\left(8 \mathrm{~J} \mathrm{~cm}^{-2} \mathrm{~h}^{-1}\right.$; Lancelot \& Mathot unpubl.). Fig. 3 shows results of ${ }^{14} \mathrm{C}$-bicarbonate incorporation into proteins by $P$. pouchetii grown under

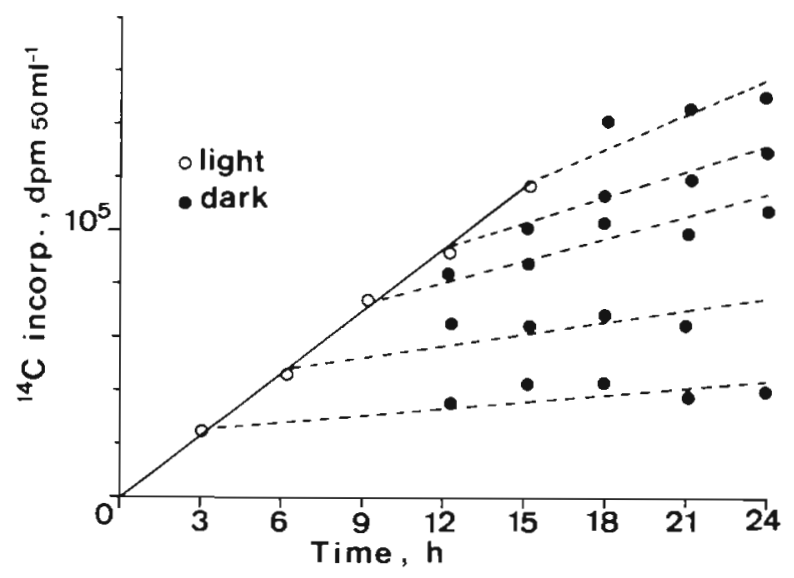

Fig. 3. Phaeocystis pouchetii. ${ }^{14} \mathrm{C}$-bicarbonate incorporation into proteins by cultured colonies grown under various light: dark cycles 
$3 \mathrm{~h}: 21 \mathrm{~h}, 6 \mathrm{~h}: 18 \mathrm{~h}, 9 \mathrm{~h}: 15 \mathrm{~h}, 12 \mathrm{~h}: 12 \mathrm{~h}$ and $15 \mathrm{~h}: 9 \mathrm{~h}$ light:dark cycles. This figure suggests that dark protein synthesis proceeds at a constant rate for each light:dark cycle tested. However, when the photoperiod is very short $(3 \mathrm{~h})$ the slope of dark protein synthesis is very weak and it cannot be completely excluded that protein synthesis stops after $12 \mathrm{~h}$ in the dark, probably by energy shortage. Nevertheless, it is clear that the rate of dark protein synthesis increases with the duration of the light period. This agrees with previously described results with pure phytoplankton species (Cook 1969, Foy \& Smith 1980).

\section{DISCUSSION}

\section{Accuracy of protein synthesis estimates}

The rate of tracer incorporation into the protein fraction as measured in these experiments reflects the actual synthesis of protein on condition that: (1) the specific activity of amino-acids, the immediate precursors of proteins, rapidly reaches and maintains the specific activity of the external labelled bicarbonate; and (2) the specific activity of protein remains low with respect to that of external bicarbonate, so that protein turnover does not significantly alter the apparent rate of tracer incorporation. This last condition was fulfilled for all our experiments. Indeed calculation of both the specific radioactivity and ${ }^{15} \mathrm{~N}$ enrichment of the protein fraction shows that isotopic equilibrium of protein was never reached during the incubations. On the other hand, ${ }^{14} \mathrm{C}$-bicarbonate incorporation into the small metabolites pool (containing amino-acids along with Krebs and Calvin intermediates) rapidly reaches a plateau, as shown in the typical example of Fig. 1 b. This is clear evidence that amino-acids and the external bicarbonate were in isotopic equilibrium. Moreover, the very close agreement observed both in the light and dark between $\mathrm{N}$-protein synthesis calculated from ${ }^{14} \mathrm{C}$ experiments, assuming a $\mathrm{C} / \mathrm{N}$ ratio of 3.3 for phytoplankton protein (Di Tullio \& Laws 1983), and from the sum of ${ }^{15} \mathrm{NO}_{3}^{-}$and ${ }^{15} \mathrm{NH}_{4}^{+}$incorporation into the proteins (Fig. 4) is further independent evidence for the accuracy of our estimates. However, direct comparison of ${ }^{14} \mathrm{C}$ and ${ }^{15} \mathrm{~N}$ estimates of protein synthesis at the end of the bloom (Table 1 ) gives a $\mathrm{C} / \mathrm{N}$ ratio of 7 , suggesting underestimation of $\mathrm{N}$ assimilation into proteins. The underestimation is probably due to isotopic dilution attributable to ammonia regeneration by microzooplankton which are present in the samples at the end of the bloom.

The high correlation level shown in Fig. 4 also suggests that nitrate and ammonia are the main if not the only sources of nitrogen for the growth of Phaeocystis

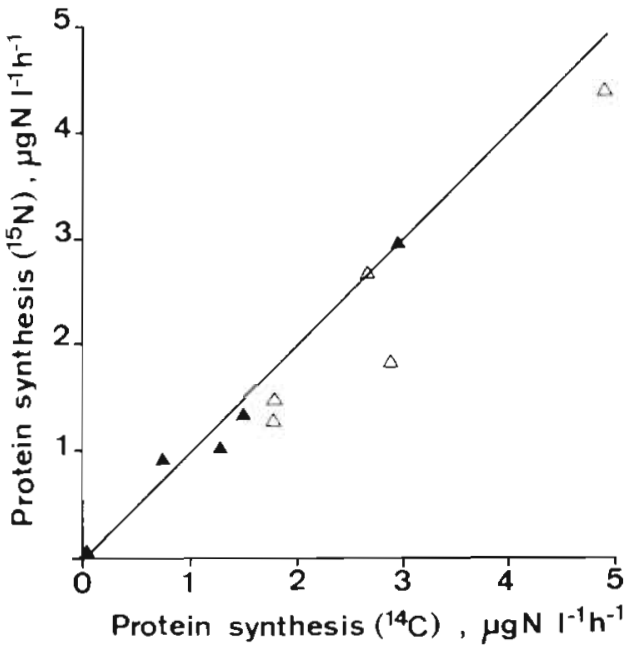

Fig. 4. Phaeocystis pouchetii. Agreement between protein synthesis rates calculated from ${ }^{14} \mathrm{C}$ and ${ }^{15} \mathrm{~N}$ incorporation measurements into proteins. $(\Delta)$ : Light process; ( $\mathbf{\Delta})$ : dark process

pouchetii colonies in Belgian coastal waters with little or no utilization of organic nitrogen (e.g. urea). It indicates in addition that contrary to oceanic phytoplankton (Laws et al. 1985) coastal phytoplankton is the main utilizer of inorganic nitrogen with insignificant uptake by microheterotrophs.

This agrees perfectly with data on bacterial activity conducted simultaneously during the Phaeocystis pouchetii bloom (Billen \& Fontigny unpubl.). Indeed these authors show that amino-acids uptake by bacteria accounts largely for their nitrogen needs. Furthermore, the data indicate that both ${ }^{14} \mathrm{C}$ and ${ }^{15} \mathrm{~N}$ are convenient tracers for the measurement of protein synthesis provided, in the case of ${ }^{15} \mathrm{~N}$ tracer, that all nitrogen sources are considered.

\section{Light protein synthesis:control by ambient inorganic nitrogen and light intensity}

The specific protein synthesis rate $\mathrm{p}\left(\mathrm{h}^{-1}\right)$ i.e. the ratio between $\mathrm{N}$-protein synthesis rate and $\mathrm{N}$-protein content of phytoplankton cells was calculated from the data of Table 1 . The cellular $\mathrm{N}$-protein content was estimated from chlorophyll a concentrations by use of a protein/chl a ratio of 58 (w:w), calculated from the data by linear regression of protein on chlorophyll a ( $\mathrm{r}=$ 0.974). This ratio was assumed constant for Phaeocystis pouchetii cells, due to the high significant level of the correlation.

Fig. Sa shows the relation between specific protein synthesis rate and ambient inorganic nitrogen for the light period. The symbols indicate the range of average incident light intensity. The curve can be satisfac- 


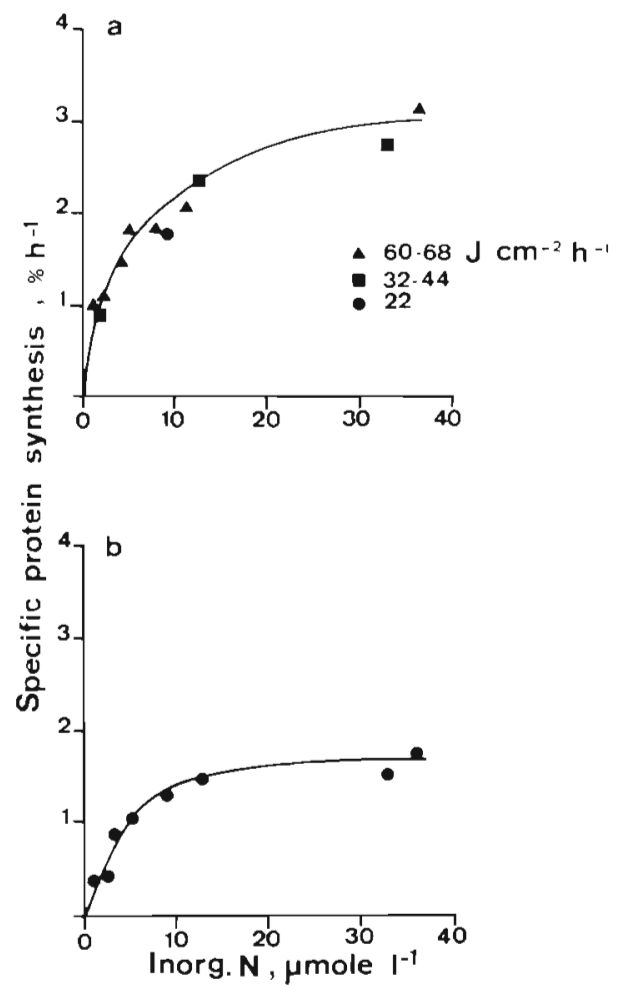

Fig. 5. Phaeocystis pouchetii. Relation between specific protein synthesis rate and inorganic nitrogen. (a) light process;

(b) dark process

torily described by a Michaelis-Menten relation. Kinetic parameters were estimated from a Lineweaver-Burk linear plot and are reported in Table 3 . The $\mathrm{K}_{\mathrm{s}}$ value of $4 \mu$ mole $1^{-1}$ agrees very well with those given by Eppley et al. (1969) for inorganic nitrogen uptake by neritic flagellates. Similarly maximal specific protein synthesis $\mathrm{p}_{\max }$ lies in the range of values reported by Goldman et al. (1981) for maximal specific growth rates of pure cultures. It could be calculated from Table 1 that Phaeocystis pouchetii cells grow at their maximum potential rate only at the beginning of the bloom.

In addition, Fig. $5 \mathrm{a}$ does not indicate any control of light protein synthesis by light intensity, at least for the range of average intensities considered in the present data. Unfortunately, the mean light intensities available to the algae were largely greater than the light saturation constant $I_{k}$ characteristic of Phaeocystis pouchetii cells. This lack of relation between protein synthesis and light should be confirmed for lower intensities. Similarly the data in Fig. 1a \& 1b suggest that, contrary to what was observed for polysaccharides and lipids, no reduction of protein synthesis rate occurs in response to the decrease in available light intensity following noon, in perfect agreement with similar data on arctic phytoplankton (Li \& Harri-
Table 3. Kinetic parameters of the relation between protein synthesis and external inorganic $\mathrm{NO}_{3}+\mathrm{NH}_{4}^{+}$, as calculated from Lineweaver-Burk linear plot

\begin{tabular}{|cccc|}
\hline $\begin{array}{c}\text { Protein } \\
\text { synthesis }\end{array}$ & $\begin{array}{c}\text { Correlation } \\
\text { coefficient }\end{array}$ & $\begin{array}{c}\text { Half-saturation } \\
\text { constant } K_{\mathrm{S}} \\
(\mu \text { mole 1 })\end{array}$ & $\begin{array}{c}\text { Specific protein } \\
\text { synthesis rate } \\
\left.\mathrm{P}_{\max }(\mathrm{h})^{1}\right)\end{array}$ \\
\hline Light & 0.96 & 4 & 0.030 \\
Dark & 0.91 & 4 & 0.018 \\
\hline
\end{tabular}

son 1982). However, more data are needed to state unequivocally the minimal light intensity threshold above which light protein synthesis by $P$. pouchetii proceeds at a constant rate.

\section{Dark protein synthesis: control by ambient inorganic nitrogen and 'previous light history'}

Fig. 5b shows the relation between dark specific protein synthesis rate, as calculated from Table 1, and ambient inorganic nitrogen. As for the light process, a Michaelis-Menten relation holds. The calculated kinetic parameters are reported in Table 3. As could be expected, the half-saturation constant is identical to that calculated for the light process. On the other hand, the maximal specific protein synthesis rate in the dark is $40 \%$ lower than the corresponding process in the light. This reduction can be attributed to the dependence of dark protein synthesis on previous light intensity history.

Control of dark protein synthesis by previous light history was established from data on cultured and natural Phaeocystis pouchetii colonies growing under ambient $\mathrm{N}$-sufficient concentration, i.e. above their $\mathrm{K}_{\mathrm{s}}$ value for inorganic nitrogen uptake. From Fig. 3 it is possible to define a minimum amount of light received above which dark protein synthesis occurs. This can be clearly seen in Fig. 6 which shows a linear positive relation between the dark:light protein synthesis ratio calculated from the data in Fig. 3 and the previous light energy available to the algae. The energetic threshold for dark protein synthesis is given by the intercept of the regression line with the $\mathrm{x}$-axis $(8 \mathrm{~J}$ $\mathrm{cm}^{-2}$ ). Thus, previous light history' $(\phi)$ of natural $P$. pouchetii colonies will be defined as the period (h) where available light intensities to the algae are greater than $8 \mathrm{~J} \mathrm{~cm}^{-2} \mathrm{~h}^{-1}$. The control by previous light history' of dark protein synthesis by natural $P$. pouchetii colonies can then be deduced from Fig. 7. This figure shows a positive linear relation between specific dark protein synthesis rate and the period $\phi$ for $\mathrm{N}$-sufficient colonies. In addition, although they fall in 
a very restricted range, these data suggest that a threshold period of about $3 \mathrm{~h}$ is needed for the occurrence of dark protein synthesis.

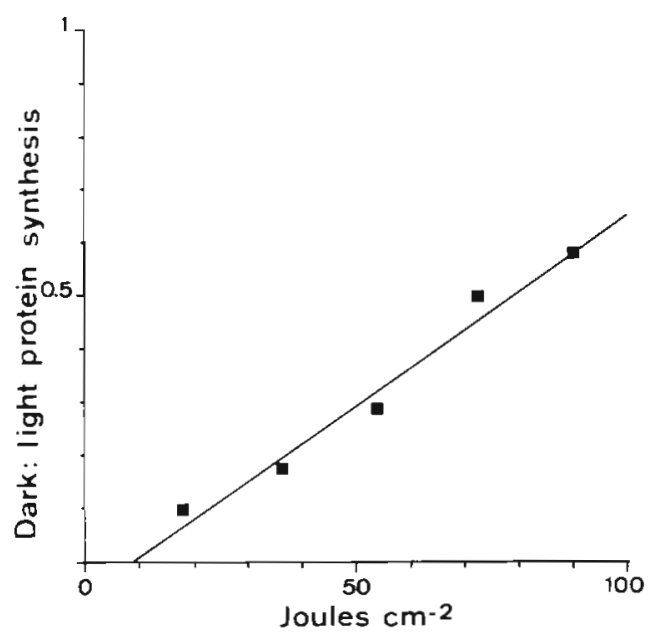

Fig. 6. Phaeocystis pouchetii. Relation between dark:light protein synthesis ratio and the previous available light energy. Cultured $\mathrm{N}$-sufficient colonies

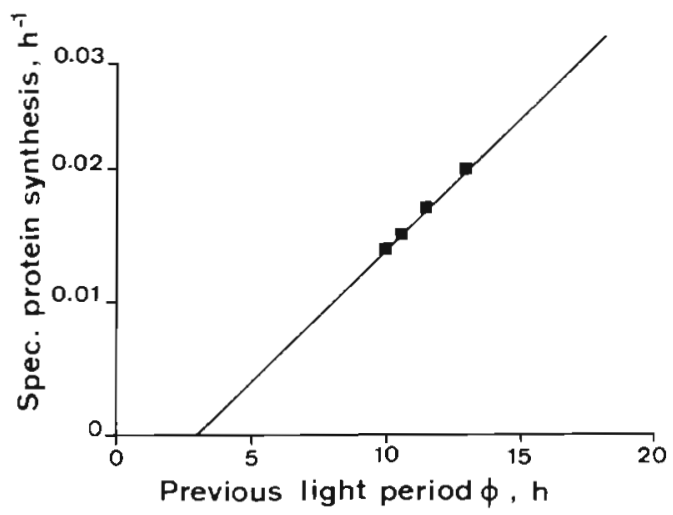

Fig. 7 Phaeocystis pouchetii. Relation between specific dark protein synthesis rate and 'previous light history $\phi$ '

\section{Daily growth: mathematical model}

On the basis of the control mechanisms described above, it is possible to establish a simple mathematical model which calculates daily integrated protein synthesis rate from the knowledge of (a) the hourly variations of available light intensity, (b) the coefficient of vertical light attenuation and (c) ambient inorganic nitrogen concentrations. Daily phytoplankton growth or net primary production can then be estimated by the use of a suitable $\mathrm{C} / \mathrm{N}$ conversion factor; a $\mathrm{C} / \mathrm{N}$ ratio of 5.6 characteristic of Phaeocystis pouchetii cells in Belgian coastal waters (Lancelot-Van Beveren 1980) has been used in this study.
Results of these calculations can then be usefully compared with those estimated by means of Platt et al.'s (1980) model from the radiocarbon method of Steeman-Nielsen (1952). This latter model generally used for estimating primary production in the water column is based only on the photosynthesis-light relation and does not take into account the dark metabolism of phytoplankton cells either in the euphotic layer during the night or in the aphotic layer for the full day. For the sake of consistency in the comparison, the protein synthesis calculation was therefore restricted to the euphotic depth. Also, the time spent in the aphotic layer was assumed to be too short for the occurrence of significant dark catabolism of protein. This requires a vertical turnover time of water masses shorter than a few days as is likely the case in the Belgian coastal zone. Light protein synthesis, on the other hand, was considered to proceed at constant rate under light intensities greater than $1 \%$ of incident available light, i. e. light intensities that determine the classical euphotic layer.

Taking these assumptions into consideration, daily protein synthesis $\mathrm{P}$ results from the integration on the depth of the daily protein synthesis calculated for each depth:

$$
P=\int_{0}^{d}(L+D)_{z} d z
$$

where $\mathrm{z}=$ depth, $\mathrm{d}=$ euphotic depth, $\mathrm{L}$ and $\mathrm{D}=$ light and dark protein synthesis at depth $\mathrm{z}$. In this equation:

$$
\mathrm{L}=0.030 \frac{\mathrm{N}}{4+\mathrm{N}} \mathrm{B} \cdot \lambda
$$

which expresses the control by ambient inorganic nitrogen of light protein synthesis. Kinetic parameters are those reported in Table 3 , and

$$
\mathrm{D}=\frac{\mathrm{N}}{4+\mathrm{N}}(0.002 \phi-0.006) \mathrm{B}(24-\lambda)
$$

with

$$
D=0 \text { if } \phi<3
$$

which expresses the double control by ambient inorganic N (Table 3) and previous light history (Flg. 7) of dark protein synthesis. In these relations, $B=$ cellular biomass; $\mathrm{N}=$ ambient inorganic nitrogen concentration; $\lambda=$ duration of the photoperiod at depth $z$, i.e. the period where light intensity is higher than $1 \%$ of surface available light; $\phi=$ 'previous light history' at depth $z$, i.e. the duration of the period where light intensity is higher than $8 \mathrm{~J} \mathrm{~cm}^{-2} \mathrm{~h}^{-1}$, the energetic threshold for dark protein synthesis.

Fig. 8 a gives results of daily phytoplankton growth calculated by means of the model for different stages of the Phaeocystis pouchetii bloom in Belgian coastal waters, together with those estimated by means of Platt 
et al.'s model. Fig $8 \mathrm{~b}$ shows the changes in ambient inorganic nitrogen and $\mathrm{N}$-protein phytoplankton biomass during the course of the same bloom. Comparison of the results of phytoplankton growth calculated with both models allows assessment of the significance of dark protein synthesis in the estimate of phytoplankton growth.

At the initial developing stage of the bloom, classical estimates of primary production underestimate phytoplankton growth. The difference can be attributed to the fact that at the growing stage of the bloom, nutrients are plentiful (Fig. 8b) and protein synthesis may proceed at a high rate during both the light and dark period. This important adaptive mechanism is ignored in the classical models of phytoplankton growth. As shown above, it is primarily the catabolism of exopolysaccharides which provides energy for this dark process in addition to that required for the maintenance of basal metabolism. The difference between the 2 determinations of primary production therefore gives an estimate for the dark mobilization of these exopolymers.

Conversely, when inorganic nitrogen is at its lowest level, protein synthesis proceeds at a lower rate and a

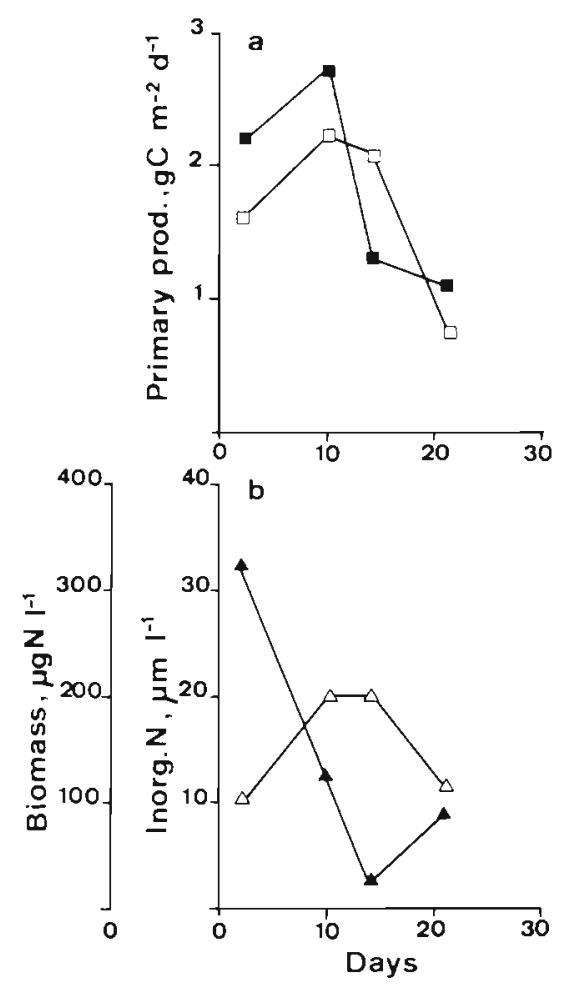

Fig. 8. Phaeocystis pouchetii. Spring bloom in Belgian coastal waters, May 1984. (a) Primary production calculated by means of the model developed in this work ( $\mathbf{a}$ ) and by that of Platt et al. (1980) (G)). (b) Changes in external inorganic N ( $\mathbf{\Delta}$ and in biomass $(\Delta)$ higher proportion of the photoassimilated carbon is devoted to the synthesis of storage products (Lancelot 1983). During this period of the bloom, the classical model clearly overestimates growth. The difference between the 2 estimates would, in this case, correspond to the catabolism of storage products for maintenance of basal metabolism during the night. However, at this stage of the bloom, the comparison between the 2 methods could have been biased by the use of an unrealistic $\mathrm{C} / \mathrm{N}$ ratio for Phaeocystis pouchetii cells. Indeed, the $\mathrm{C} / \mathrm{N}$ ratio of 5.6 determined by LancelotVan Beveren (1980) was characteristic of developing $P$. pouchetii cells. No information is available on the $\mathrm{C} / \mathrm{N}$ of these cells at the stationary stage of their growth. As an example, if a $\mathrm{C} / \mathrm{N}$ ratio of 7.7 , which is characteristic of summer phytoplankton in Belgian coastal waters, is applied to the model, calculated values of phytoplankton growth are $35 \%$ higher than those calculated for 5.6 $\mathrm{C} / \mathrm{N}$ ratio. The need for an accurate determination of $\mathrm{C} / \mathrm{N}$ ratio of phytoplanktonic cells therefore constitutes a limitation to the model.

The mathematical formulation of control by light and ambient inorganic nitrogen of light and dark protein synthesis, although oversimplified, has been shown to be a simple way of estimating daily phytoplankton growth in the water column from the easily measurable variables of ambient inorganic nitrogen and incident light intensities. This is very important from an ecological point of view, because, after more than $30 \mathrm{yr}$ of intensive research in phytoplankton ecology, there are no satisfactory means for estimating daily net primary production. However, some assumptions of the model have to be specified, i.e. the control of light protein synthesis rate at the lowest light intensities, and the occurrence of dark catabolism of protein and the variations in cellular $\mathrm{C} / \mathrm{N}$ ratio.

Acknowledgements. This work was financially supported by the E.E.C., contract ENV. $862 \mathrm{~B}$ and by the Belgian Ministry of Science Policy. We thank E. Stainier for nutrient determinations and we are grateful to Dr. A. Davies for providing strains of Phaeocystis pouchetii colonies.

\section{LITERATURE CITED}

Armstrong, F. A., Stems, A. J., Strickland, J. D. H. (1967). The measurement of upwelling and subsequent biological processes by means of the Technicon auto-analyses. Deep Sea Res. 14: 381-387

Collos, Y. (1984). Transient situations in nitrate assimilation by marine diatoms. $V$. Interspecific variability in biomass and uptake during nitrogen starvation and resupply. Mar. Ecol. Prog. Ser. 17: 25-31

Cook, J. R. (1966). Photosynthetic activity during the division cycle in synchronized Euglena gracilis. Pl. Physiol. 41: 821-825 
Cuhel, R. L., Ortner, P. B., Lean, D. R. S. (1984). Night synthesis of protein by algae. Limnol. Oceanogr. 29: $731-744$

Di Tullio, G. R., Laws, E. A. (1983). Estimates of phytoplankton $\mathrm{N}$ uptake based on ${ }^{14} \mathrm{CO}_{2}$ incorporation into protein. Limnol. Oceanogr. 28: 177-185

Eppley, R. W., Peterson, B. J. (1979). Particulate organic matter flux and planktonic new production in the deep ocean. Nature, Lond. 39: 111-120

Eppley, R. W., Rogers, J. N., McCarthy, J. J. (1969). Halfsaturation constants for uptake of nitrate and ammonium by marine phytoplankton. Limnol. Oceanogr. 14: 912-929

Eppley, R. W., Renger, E. H., Harrison, W. G. (1979). Nitrate and phytoplankton production in Southern California coastal waters. Limnol. Oceanogr. 24: 483-494

Foy, R. H., Smith, R. V. (1980). The role of carbohydrate accumulation in the growth of planktonic Oscillatoria species. Br. Phycol. J. 15: 139-150

Glibert, P. M., Goldman, J. C., Carpenter, E. J. (1982). Seasonal variations in the utilization of ammonium and nitrate by phytoplankton in Vineyard Sound. Massachusetts, U.S.A. Mar. Biol. 70: 237-249

Goldman, J. C. (1980). Physiological processes, nutrient availability and the concept of relative growth in marine phytoplankton ecology. In: Falkowski, P. G. (ed.) Primary productivity in the sea. Plenum, New York, p. 179-194

Goldman, J. C., Dennett, M. R., Riley, C. R. (1981). Marine phytoplankton photosynthesis and transient ammonium availability. Mar. Biol. Lett. 2: 323-331

Guillard, R. R. L., Ryther, J. H. (1962). Studies of marine planktonic diatoms I. Cychotella nana Hustedt and Denotula confervacea (Cleve) Gran. Can. J. Microbiol. 8: 229-239

Lancelot-Van Beveren, C. (1980). A statistical method to estimate the biochemical composition of phytoplankton in the Southern Bight of the North Sea. Estuar. Coast. mar Sci. 10: $467-478$

Lancelot, C. (1983). Metabolic changes in Phaeocystis pouchetii (Hariot) Lagerheim during the spring bloom in Belgian coastal waters. Estuar coast. Shelf. Sci. 18: 593-600

Lancelot, C., Mathot, S. (1985a). Biochemical fractionation of primary production by phytoplankton in Belgian coastal waters during short- and long-term incubations with ${ }^{14} \mathrm{C}$ bicarbonate. I. Mixed diatom population. Mar. Biol. 86 (3): $219-226$

Lancelot, C., Mathot, S. (1985b). Biochemical fractionation of primary production by phytoplankton in Belgian coastal waters during short- and long-term incubations with ${ }^{14} \mathrm{C}$ bicarbonate. II. Phaeocystis pouchetii colonial population. Mar. Biol. 86 (3): 227-232
Laws, E. A., Harrison, W. G., Di Tullio, G. R. (1985). A comparison of nitrogen assimilation rates based on ${ }^{15} \mathrm{~N}$ uptake and autotrophic protein synthesis. Deep Sea Res. $32(1): 85-95$

Li, W. K. W. Harrison, W. G. (1982). Carbon flow into the endproducts of photosynthesis in short-and long-incubations of a natural phytoplankton population. Mar. Biol. 72: $175-182$

Lorenzen, C. (1967). Determination of chlorophyll and phaeopigments: spectrometric equations. Limnol. Oceanogr. 12: 343-347

McCarthy, J. J., Taylor, W. R., Taft, J. L. (1977). Nitrogenous nutrition of the population in the Chesapeake Bay. 1. Nutrient availability and phytoplankton preferences. Limnol. Oceanogr. 22: 996-1011

Parsons, T. R., Takahashi, M., Hargrave, B. (1977). Biological oceanographic processes. 2nd edn. Pergamon Press, Oxford, p. 105-111

Platt, T., Gallegos, C. L. (1980). Modelling primary production. In: Falkowski, P. G. (ed.) Primary productivity in the sea. Plenum Press, New York, p. 339-362

Platt, T., Gallegos, C. L., Harrison, W G. (1980). Photoinhibition of photosynthesis in natural assemblages of marine phytoplankton. J. mar. Res. 38 (4): $687-701$

Preston, T., Owens, N. J. P. (1983). Interfacing an automatic elemental analyser with an isotope ratio mass spectrometer: the potential for fully automated Total Nitrogen and Nitrogen-15 analysis. Analyst 108: 971-977

Priscu, J. C., Priscu, L. R. (1984). Photosynthetate partitioning by phytoplankton in a New Zealand coastal upwelling system. Mar. Biol. 81: 31-40

Probyn, T. A. (1985). Nitrogen uptake by size-fractionated phytoplankton populations in the southern Benguela upwelling system. Mar. Ecol. Prog. Ser. 22: 249-258

Redalje, D. G. (1980). The effects of environmental factors on the general patterns of carbon metabolism in marine phytoplankton. Ph. D. thesis, Univ. of Hawaii

Rivkin, R. B., Voytek, M. A., Seliger, H. H. (1982). Phytoplankton division rates in high limited environments: Two adaptations. Science 215: 1123-1125

Slawyk, G., Mclsaac, J. J. (1972). Comparison of two automated ammonium methods in a region of coastal upwelling. Deep Sea Res. 19: 1-4

Steeman-Nielsen, E. (1952). The use of radioactive carbon $\left({ }^{14} \mathrm{C}\right)$ for measuring organic production in the sea. $\mathrm{J}$. Cons. perm. int. Explor. mer 18: 117-140

Veldhuis, M. J. W., Admiraai, W (1985). Transfer of photosynthetic products in gelatinous colonies of Phaeocystis pouchetii (Haptophyceae) and its effect on the measurement of excretion rate. Mar. Ecol. Prog. Ser 26: 301-304

This article was presented by Professor E. Paasche; it was accepted for printing on June 20,1986 